\title{
Technological maturity in the world petrochemical industry
}

\section{Javier Jasso Villazul}

Research Professor,

Economics Division,

Center for Economic

Research and Training

(CIDE), Mexico.
This article presents a methodological and empirical approach to the measurement of technological maturity in a process industry, such as petrochemicals, at the international level. The main conclusion is that the degree of technological maturity determined in the exercise may vary, depending on the indicator used for measuring the life cycle of the industry. This finding is very important because the conventional indicators of market dynamism or production do not always reflect the degree of technological maturity of an industry or sector. Since technology is a decisive factor in the degree of maturity, other variables also need to be incorporated, especially regarding the technological dimension. The methodology of the present study includes a typology for each result with respect to competitiveness, for each form of maturity, with emphasis on the role and characteristics of technology as a source of long-term competitiveness (sections II and III), using market, production and technology variables located around the life cycle of products and the value chain. In the analysis of the evolution of the petrochemical industry and its production and technological features, special emphasis is placed on two types of production processes (continuous and batch-type processes) and two types of business: commodities, and special petrochemical products (sections IV and V). After presenting the results and types of technological maturity for each variable, the correlation of the variables used is assessed (sections VI and VII). Finally, some conclusions are presented and the lines of research suggested by this exercise are outlined (section VIII). 


\section{Introduction}

... technological change is extremely uneven over time; in each industry and economic sector and, geographically, in each region and country. The spread of clusters of broadly adaptable technological innovations is capable of giving a substantial boost to the growth of the economic system, ... however, these new "technology systems" eventually mature and tend to produce different effects on investment and employment.

Christopher Freeman, John Clark and Luc Soete

Competitive advantages are linked to the degree of technological maturity of products and processes. The latter, in turn, is connected with the know-how applied to the creation or improvement of new products, processes or production techniques, including machinery, organization and production process design. Consequently, specialization of marketing and production on mature or innovative products is a reflection of the effort made by the agents to innovate and, to a large extent, to survive or maintain their position in the international market. ${ }^{1}$

This article seeks to measure the technological maturity of the petrochemical industry (PCI). ${ }^{2}$ The aim is to show that it is necessary to include technological maturity variables in order to determine more precisely the form of specialization in markets and products and the competitiveness of an industry or sector. The measurement includes both qualitative and quantitative indicators, in view of the complexity of assessing the technological maturity of an industry or economic sector.

Because of the technological changes and innovations which have taken place between its creation earlier in the twentieth century and recent years, the PCI has reached a level of technological development which justifies its description as a technologically mature industry.

However, this innovation and evolution has not been uniform or identical at the level of the different products or branches of the industry. Thus, although the PCI may be described in general as a technologically mature industry, there are products or branches in it which may be singled out as innovative.

A more detailed analysis will allow this generalization to be made more specific and contribute to theoretical analysis and the definition and application of more effective public policies. $\square$ The author wishes to express his thanks for the comments and suggestions made on various previous versions discussed at research seminars in CIDE, especially those of Kurt Unger and of an anonymous ECLAC referee.

${ }^{1}$ For more details of the relation between technological development and competitiveness see, among others, Nelson and Winter (1982), Freeman, Clark and Soete (1982), Fajnzylber (1991), ECLAC (1993), Arjona and Unger (1996) and Jasso (1997).
${ }^{2}$ Technological maturity is described later in this article. In the petrochemical industry, production differentiation covers a wide variety of products ranging from specialized petrochemicals to commodities. 


\section{II}

\section{Technological maturity as a result of market, production and/or technological factors}

In this article it is suggested that technological maturity should be linked to the market results and the production and technological position of each product in a given industry. The production and technological position implies a technological level which may be termed "innovative" when there is a substantial technological effort, or "mature" when this is not the case.

The position of each branch of the PCI may display an upward trend or be the same as its initial situation, in dynamic or static market segments; ${ }^{3}$ this determines its status as mature or innovative, which is reflected in the efforts made and results obtained in terms of the market, production and technology. In the approach set forth in the present article, the measurement of technological maturity is linked with the level of technological dynamism, as reflected in the type of product -innovative or mature- and the type of market: dynamic or static (figure 1).

The technological innovation process has the following features:

i) it is dynamic: that is to say, it changes with time and with the strategies and circumstances of the actors involved. This dynamism and change means that firms are guided by their perception that there are unexploited opportunities;

ii) it is differentiated, which means that its results and performance are specific to the particular characteristics and conditions of each industry, region, company or country;
FIGURE 1

Technological maturity as a function of market dynamism and technological dynamism

Market dynamism

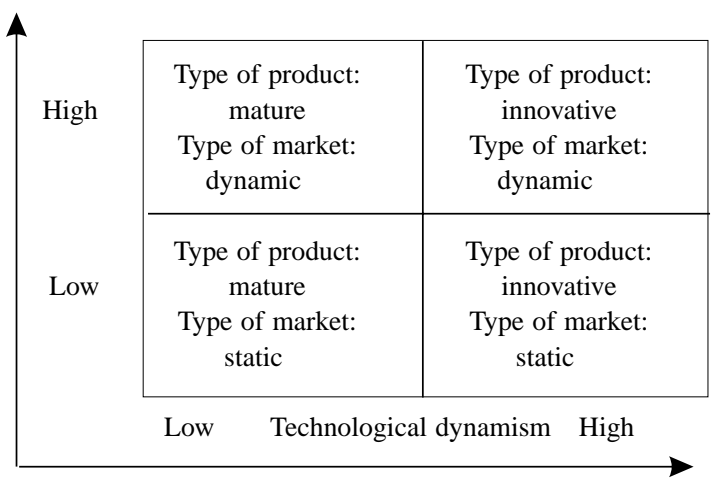

Source: Prepared by the author.

iii) it is cumulative, reflecting the possibility of incorporating experience and learning to build up and create knowledge;

iv) it is capable of being appropriated, so that technological results can be protected and hence sold or kept by the innovator, who thus obtains benefits from his innovation, and

v) the circumstances and efforts of the participating actors and the networks that exist between them mean that the opportunities are different for each industry, institution, country or region.

\footnotetext{
3 Dynamic products are those which have an above-average growth rate compared with the rest of the products and also have a high technological content.
} 


\section{III}

\section{Analysis of technological maturity}

The technological maturity of the PCI will be measured by the share of each branch of the industry in the world market; the dynamism of the market, of production, and of patent applications; the branch's location in the production chain, and its technological characteristics.

This proposed methodology analyses the technological maturity process and determines whether, in the light of different variables for measuring such maturity, the position by products is in line with each variable.

The dependent variable is technological maturity, while the independent variables correspond to the market share, associated with the dynamism of the market, the dynamism of production, the dynamism of patent applications, the location in the production chain, and the taxonomy of the technology (figure 2).

Identification of the stage at which each product or process is located in the technological life cycle and its position in the market is an important criterion for determining the degree of maturity of products or processes (figure 3). These variables are located around the life cycle of PCI branches in an "S" or Engel curve. Analysis of the cycle is important in order to identify the type of commercial and technological specializa- tion and the stages of innovation, maturity and decline. The products which offer the greatest growth potential (generally innovative products) are those which are at the start of the curve. The opportunities associated with each type of technology are also located in this stage of the cycle.

As products advance in their life cycle their growth trend is slower, because of the entry of new imitative competitors who tend to saturate the technological opportunities: this causes the growing maturity of the products in question, which are more and more standardized and become simple commodities (figure 3 ).

The degree of technological maturity is thus related with the life cycle of the product. In the initial stages of development and application of technologies, the innovations are predominantly in products and correspond above all to specialties (figure 3 ), but in the following stages -saturation and declinethey are mainly in processes, especially for the production of commodities.

FIGURE 2

Categories and variables used for measuring the technological maturity of products or branches

\begin{tabular}{lll}
\hline \multicolumn{1}{c}{ Variables used } & & Categories \\
\hline $\begin{array}{l}\text { "y" axis: } \\
\text { Market share in relation with } \\
\text { a, b, c, d and e }\end{array}$ & High or low & Comparative, market \\
& & \\
"x" axis: & & \\
a) Market dynamism & Dynamic or static & Market \\
b) Production dynamism & Mature or innovative & Product \\
c) Rate of patent applications & High or low & Patent \\
d) Production chain & Basic (commodities) or final (specialties) & Production chain \\
e) Technological taxonomy & Mature: supplier-dominated, with economies of scale & Evolutionary \\
& Innovative: specialized science-based suppliers & \\
\hline
\end{tabular}


FIGURE 3

Innovation and maturity: the technological life cycle

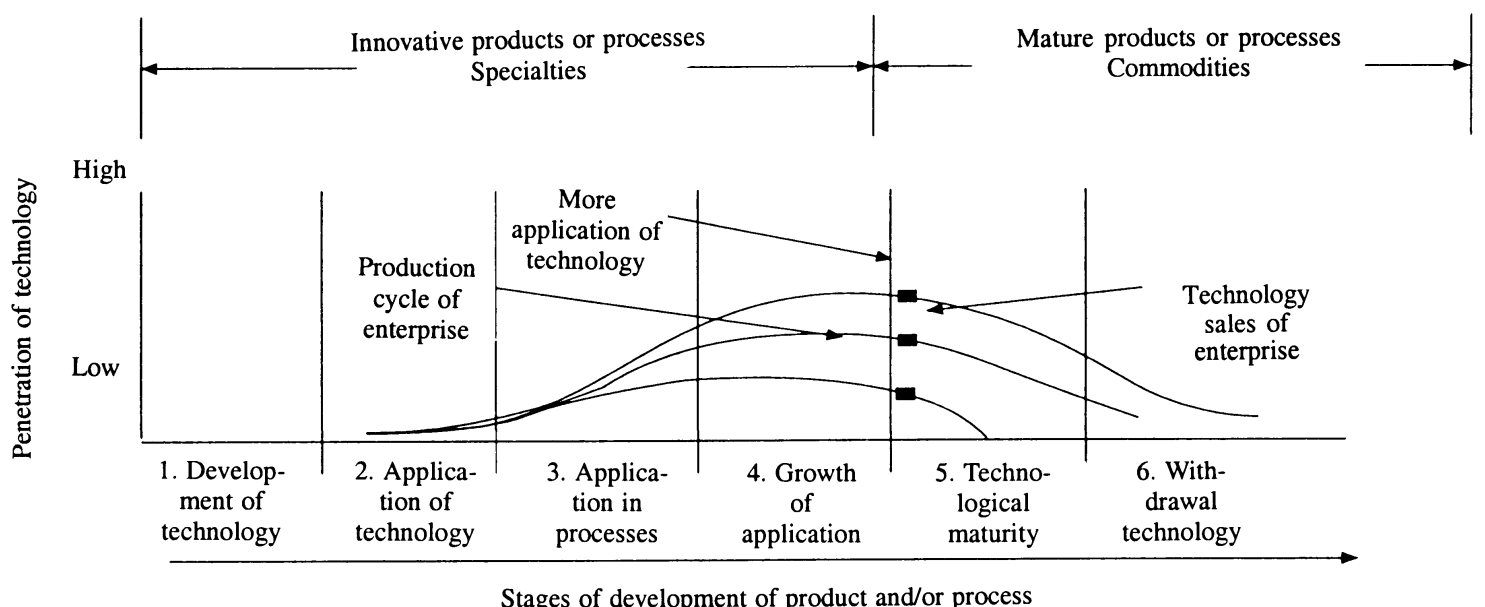

\section{IV}

\section{The petrochemical industry as a subject of analysis}

\section{The importance and definition of the petrochemical industry: its products and the production chain}

It is important to study the degree of maturity of the PCI, because this industry has contributed to the birth and evolution of some of the industries that form the present techno-economic paradigm, such as those of new materials, biotechnology, microelectronics, telecommunications and genetic engineering. ${ }^{4}$

The PCI is defined as a set of activities consisting of 18 branches based on three-digit groups of the Standard International Trade Classification (SITC). ${ }^{5}$

\footnotetext{
${ }^{4} \mathrm{~A}$ techno-economic paradigm is a model and pattern of solutions for given technological problems, based on a selection of principles derived from the natural sciences and applied technology (Dosi, 1982).

${ }^{5}$ The 18 branches in question are listed in table 1 and some of them are reflected in the petrochemical chain shown in figure 4.
}

This definition takes the PCI in a broad sense at the production level and includes its international performance (table 1). The selected set of activities includes petrochemicals which are separated out directly from petroleum in the form of products, without undergoing any changes in their chemical composition, and also other petrochemicals from intermediate stages or steps in their synthesis, before being turned into final products.

In other words, it covers the petrochemical chain from the most basic petroleum products (naphthas, aromatics, olefins and natural gas) up to special petrochemical products (table 1 and figure 4 ).

The term "intermediate petrochemical product" has been coined to denote chemical compositions at stages intermediate between one or more raw materials and the final marketed products ${ }^{6}$ (figure 4 ).

\footnotetext{
${ }^{6}$ Although some petrochemical products may be considered as chemicals, in this study we will refer indistinctly to both concepts when talking about organic chemistry.
} 
TABLE 1

Branches of the international

petrochemical industry

\begin{tabular}{|c|c|c|}
\hline & $\begin{array}{l}\text { Branches } \\
\text { (SITC } \\
\text { groups) }\end{array}$ & Name of branch \\
\hline 1 & 233 & Latex, rubber, SBR, oil derivatives, etc. \\
\hline 2 & 266 & Synthetic fibres, nylon, polyester, polyamides \\
\hline 3 & 334 & Petroleum products \\
\hline 4 & 511 & $\begin{array}{l}\text { Ethylene, butylene, propylene, butadiene, } \\
\text { benzene, xylene, toluene, styrene, cyclohexane, } \\
\text { ethylbenzene }\end{array}$ \\
\hline 5 & 512 & Alcohols, phenols and their derivatives \\
\hline 6 & 513 & Carboxylic acids, anhydrides, halides \\
\hline 7 & 514 & Acrylonitrile, amines, anilines \\
\hline 8 & 516 & $\begin{array}{l}\text { Acetaldehyde, acetone, formaldehyde, ethylene } \\
\text { oxide, propylene oxide }\end{array}$ \\
\hline 9 & 522 & $\begin{array}{l}\text { Ammonia, carbon black, nitric acid, aluminium } \\
\text { hydroxide, etc. }\end{array}$ \\
\hline 10 & 533 & Pigments, paints, varnishes, etc. \\
\hline 11 & 551 & Essential oils and perfume materials \\
\hline 12 & 562 & Urea, ammonium sulphate, phosphates, etc. \\
\hline 13 & 572 & Explosives and pyrotechnic products \\
\hline 14 & 582 & PET, polyamides, polycarbonates and other resins \\
\hline 15 & 583 & $\begin{array}{l}\text { Polyethylene, polypropylene (PP), polyvinyl } \\
\text { chloride (PVC), ABS-SAN, etc. }\end{array}$ \\
\hline 16 & 584 & Cellulose acetate, esters, ethers, etc. \\
\hline 17 & 591 & Insecticides, fungicides, disinfectants, herbicides \\
\hline 18 & 598 & $\begin{array}{l}\text { Plasticizers, oil additives, anti-knock } \\
\text { preparations, etc. }\end{array}$ \\
\hline
\end{tabular}

Source: Prepared by the author on the basis of the Standard International Trade Classification (SITC).

This definition is useful for securing compatibility between different statistical sources and series, particularly at the levels of aggregation used by the various international classifications of trade, production and patents. ${ }^{7}$

\section{Evolution of the petrochemical industry}

At the world level, the PCI has been one of the fastest-growing industries, with high profit rates. ${ }^{8}$ Innovatory trends in the PCI were initially observed in the innovation activities of the pioneering companies in the 1950s and 1960s, which was termed a period of

\footnotetext{
${ }^{7}$ This includes compatibility of the three-digit SITC trade classifications, with United Nations (1993 and 1994) data on world production, and the classification of the United States Patent Office for patents registered in that country.

${ }^{8}$ Its most flourishing period was from the 1950 s to the 1970 s.
}

"technology push". The typical innovation model was based on fundamental sciences, giving rise to new petrochemical product and process designs (figure 5).

As a result of this rapid expansion of the PCI, petrochemical companies -especially the transnationals- began to specialize in product lines in which they had some kind of market, production or technological advantage.

In their process of internationalization, these companies set up subsidiaries in oil-producing countries in order to guarantee a supply of petroleum or basic petroleum products and to serve the local market, and they reproduced the production and trading model of the parent firm in them. This internationalization strategy did not initially include major research and development activities.

In the decades in question the oil-producing companies increased their world market shares in operations with greater forward linkages in the petrochemical chain, manufacturing basic and intermediate petrochemical products and some synthetic plastics. At the same time, the chemical companies specialized in the final stages of the chain and showed a tendency to backward integration to include the manufacture of intermediate products, but without giving up the production of final goods.

This led to a process of restructuring of the PCI, in which the main petrochemical companies had built up sufficient technological capacity to occupy the position of leaders, creating a technological tradition in some products or product lines throughout the technological path. ${ }^{9}$ This specialization and growing accumulation of production and technological capabilities has been one of the main barriers to the entry of possible new competitors or imitators. ${ }^{10}$

This form of competition gave rise to an arranged and oligopolistic market by the late $1960 \mathrm{~s}$ and the 1970s. At the end of the 1970s, some $90 \%$ of world petrochemical production came from the United States, the Western European countries and Japan, which also made growing investments in the PCI of other countries.

\footnotetext{
9 With regard to technological tradition, see Achilladelis, Schwarzkopf and Cines (1990).

${ }^{10}$ Copying products or processes through reverse engineering or the consultation of patents is more complicated in the PCI than in other industries because its products have very precise physical and chemical characteristics in which the production process is of decisive importance for progressing from the prototype level to full-scale industrial volumes of production.
} 
FIGURE 4

The petrochemical chain: products and branches ${ }^{a}$

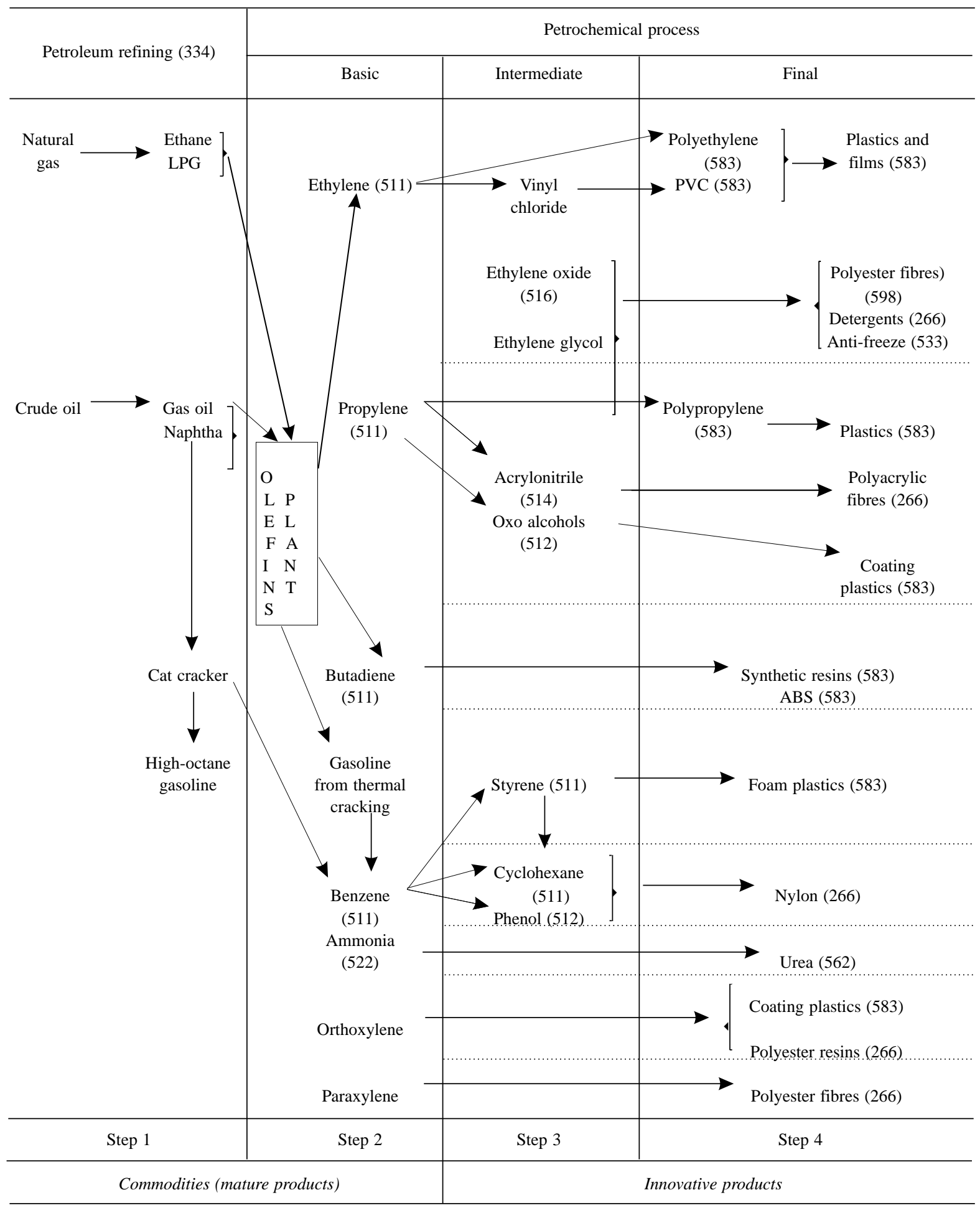

Source: Prepared by the author.

a The numbers in brackets correspond to some of the selected branches whose products are listed in table 1. 
FIGURE 5

Supply push (first generation)

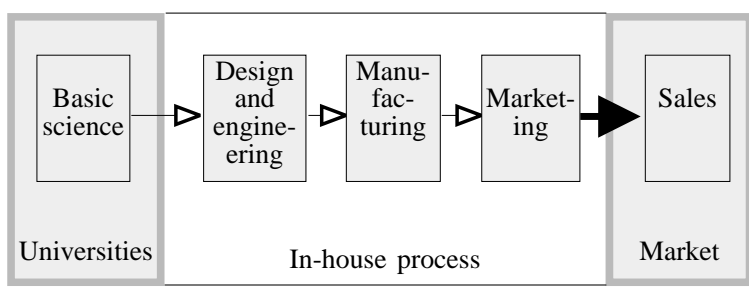

Source: Prepared by the author.

In the early 1980 s, demand began to play a more important role as a force for innovation, and companies tended to make changes in their products and processes in response to market needs (figure 6).
FIGURE 6

Demand push (second generation)

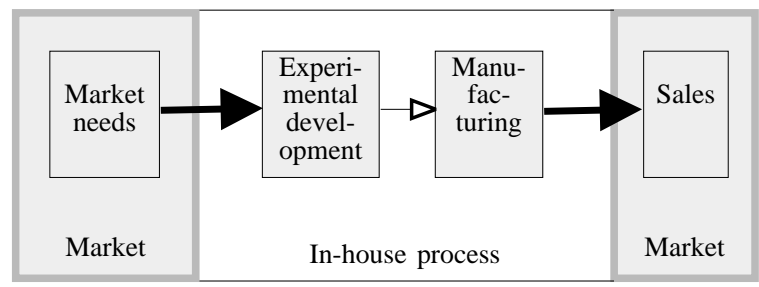

Source: Prepared by the author.

From the mid-1970s to the 1980s, the entry of new competitors gave rise to a supplementary innovation model, midway between technology and demand pushes, which is now characteristic of innovation activities in the PCI. ${ }^{11}$

\section{V}

\section{Production and technological features of the petrochemical industry}

Ever since it arose early in the twentieth century, the PCI has been marked by the technological change ${ }^{12}$ associated with scientific and technical processes in the chemical industry. The system of continuous production predominates, as do high capital-product and capital-labour ratios and marked effects of scale (Chudnovsky, López and Porta, 1994).

These features give rise to supply patterns which are highly concentrated in the producer countries: a phenomenon which is particularly marked in the case of certain developing countries and companies.

\section{Continuous and batch-type production processes (thermal cracking and catalytic cracking)}

The most important change in the PCI has been the transition from batch or non-continuous production processes to continuous processes. These latter processes have made it possible to apply economies of scale in the construction of the plants and in labour costs, to avoid heat losses, to facilitate the monitoring and control of chemical reactions, to reduce considerably the unit production costs of the majority of the most important chemical products, to raise quality, and to achieve greater uniformity of the products.
The new continuous production pattern became known for the first time in the dyestuffs industry. Although the first synthetic dyestuffs and innovations in this field were discovered by English inventor/entrepreneurs, by the end of the nineteenth century the lead in this field had undoubtedly been taken over by German industry (Freeman, 1974).

Thermal and catalytic cracking ${ }^{13}$ were part of the changes made in the oil refining process. The relations between IG Farben and Standard Oil in the 1920s and 1930s marked the culmination of a process of evolutionary development which had begun in 1900-1913 with the process of cracking the heavy components of petroleum to produce gasoline.

\footnotetext{
${ }^{11}$ For more details of the innovation process in the industry, see Rothwell (1994), and with regard to innovation in the chemical and/or petrochemical industry see Walsh (1984), Chapman (1991), Achilladelis, Schwarzkopf and Cines (1990), Bower (1985), Freeman (1974), Gutiérrez (1988), Unger, Saldaña, Jasso and Durand (1994) and Chudnovsky and Porta (1997).

12 Technological change is the process of changes in a product, process or production technique which involves the introduction of new aspects or the improvement of existing ones.

${ }^{13}$ In the 1920 s it quickly became clear that any subsequent progress in the cracking process would probably be based on catalytic techniques (Freeman, 1974).
} 
Characteristics of commodities and specialties, and differences between them

\begin{tabular}{lll}
\hline & Commodities (mature products) & Specialties (innovative products) \\
\hline Type of process & Continuous-flow & Small batches \\
Process characteristics & Stable and controlled & New products \\
Marketing strategies & Standard & Differentiation \\
Type of competition & Prices & Technology/new products \\
Source of profitability & Scale of production & Low volume, high prices \\
Type of knowledge & Widely known & Specific \\
Age of equipment & Latest generation & Older generations \\
Knowledge base & Basic processes & Chemical engineering \\
\hline
\end{tabular}

Source: Prepared by the author.

The combined effect of the change to continuous processes, the increasingly large scale of operation, the use of catalytic processes, the complexity of plant design and the use of petrochemical products as basic materials gave the great chemical and petrochemical companies a dominant position in the development of new processes from the First World War onward (Freeman, 1974).

\section{Commodities and specialty products as differentiated areas of business}

The production and technological features described above have resulted in the PCI having two strongly differentiated areas of business (figure 7): i) commodities, with generally stable, controlled and optimized continuous-flow production processes and price-based marketing strategies, and ii) specialty products, with non-continuous or small batch processes and marketing strategies aimed at the launching of three or four new products each year.

These differences mean that the know-how associated with each of these areas of business is not complementary with the other. Non-continuous processes require specialized know-how on chemical engineering, whereas continuous processes call for know-how on basic processes, last-generation equipment, and constant efforts to optimize the processes. Thus, as the know-how required in the two fields is different, specialization in commodities does not necessarily lead to the production of specialties. In other words, there is not much room for shared know-how and savings through synergies (figure 7).

This limitation is important for understanding the weak situation of many Latin American countries, which, in general, have tended to concentrate on the first of these fields. However, there are small locally owned companies in Argentina, Mexico and Brazil which manufacture products with a higher content of innovation and research (including pharmaceutical chemicals, plasticizers and pesticides). The results of each technological opportunity are intimately linked with commercial, production and technological specialization (figure 2).

It may be concluded from this analysis that the different patterns of specialization will generally have different possibilities of technical progress and long-term growth and that it is advantageous for a country to be able to compete successfully in an industry, branch or product whose markets offer good prospects of development and involve key technologies (Arjona, 1995; Amable, 1993): i.e., those of innovative products. 


\section{VI}

\section{The initial approach: international market shares}

This first indicator -the PCI's share of the international market - is combined with the indicators proposed here for measuring the technological maturity of the industry.

The initial analysis of the technological maturity of the PCI is based on the variables proposed for the indicators of revealed comparative advantages, through the indicator of the PCI's share of the international market, represented here by the imports of the member countries of the Organization for Economic Cooperation and Development (OECD).

In other words, the PCI's share is measured in relation to the OECD's imports of petrochemicals and the total imports of the OECD; likewise, the share of each branch of the petrochemical industry is measured in terms of its share in the total world market (all branches) and the world petrochemical market (only the petrochemical branches). ${ }^{14}$

The indicator used to measure the PCI's share in the world market is as follows:

Share of $\mathrm{PCI}=M i / M t$, where $M t=$ total $\mathrm{OECD}$ imports and $M i=$ OECD imports of petrochemical products.

Between 1980 and 1995, international trade in petrochemical products grew at an average rate of $7 \%$ per year (i.e., $60 \%$ faster than world production), while its share in total world imports was $9.5 \%$ in 1980 and $7.4 \%$ in 1993 (figure 8).

The growth rate of the share of world imports accounted for by the PCI as a whole went down by almost $23 \%$ over the period in question, declining from $0.5 \%$ in 1980 to $0.4 \%$ in 1993 . This clearly illustrates the relative maturity of the PCI as a whole on the market side (table 2).

${ }^{14}$ The data used are taken from the Competitive Advantage of Nations (CAN) model developed by the Economic Commission for Latin America and the Caribbean (ECLAC, 1994).

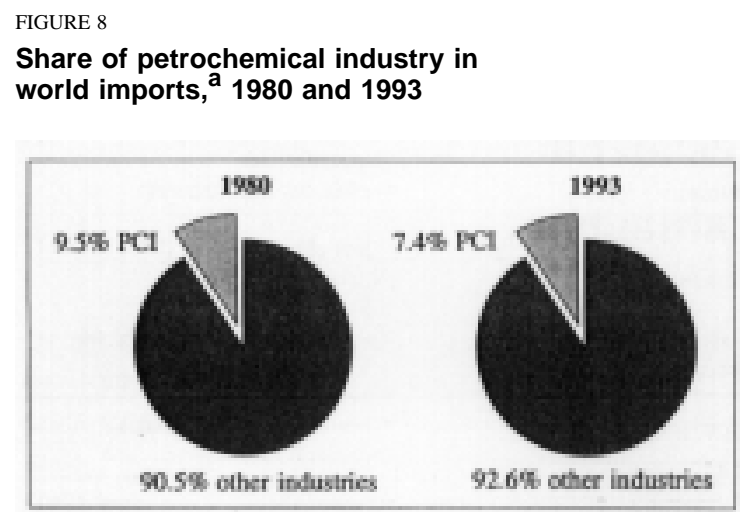

Source: Prepared by the author.

a As represented by the imports of the OECD countries.

FIGURE 9

Shares of mature and innovative branches of the petrochemical industry, 1980 and 1990

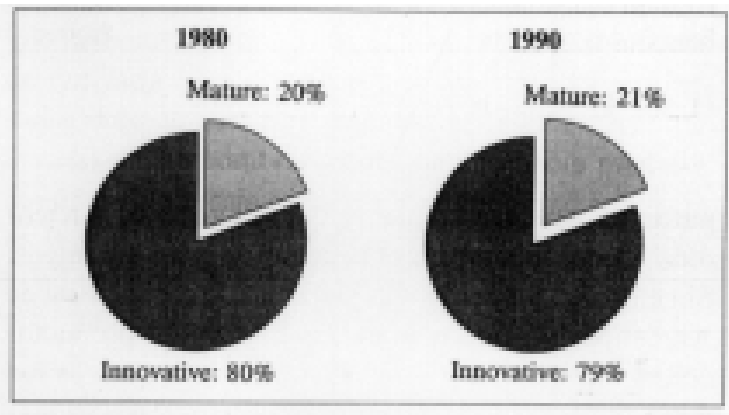

Source: Prepared by the author.

This increasing maturity also reflects increasing maturity in terms of the branches of the PCI: thus, the mature branches increased from $20 \%$ of the whole in 1980 to $21 \%$ in 1993 (figure 9).

There is a high degree of concentration of production, as just a few branches account for a high proportion of total production. Thus, the 
TABLE 2

Competitiveness of the world petrochemical industry, $1980-1993^{a}$

\begin{tabular}{|c|c|c|c|c|c|}
\hline & & \multicolumn{2}{|c|}{1980} & \multicolumn{2}{|c|}{1993} \\
\hline & & World market & PCI $(\%)$ & World market & PCI $(\%)$ \\
\hline \multicolumn{6}{|c|}{ World petrochemical industry: } \\
\hline Average & & 4.77 & 50.00 & 3.69 & 50.00 \\
\hline Total & & 9.54 & 100.0 & 7.38 & 100.00 \\
\hline \multicolumn{6}{|c|}{ Branches $^{\mathrm{b}}$ with the largest shares (innovative branches) } \\
\hline Average & & 0.95 & 9.98 & 0.73 & 9.86 \\
\hline Total & & 7.61 & 79.80 & 5.82 & 78.87 \\
\hline 1 & 334 & 4.64 & 48.69 & 1.95 & 26.41 \\
\hline 2 & 583 & 0.94 & 9.82 & 1.18 & 15.98 \\
\hline 3 & 598 & 0.48 & 5.07 & 0.66 & 8.94 \\
\hline 4 & 514 & 0.35 & 3.64 & 0.62 & 8.45 \\
\hline 5 & 582 & 0.40 & 4.24 & 0.48 & 6.49 \\
\hline 6 & 533 & 0.20 & 2.09 & 0.32 & 4.32 \\
\hline 7 & 513 & 0.24 & 2.53 & 0.31 & 4.16 \\
\hline 8 & 522 & 0.36 & 3.73 & 0.30 & 4.12 \\
\hline \multicolumn{6}{|c|}{ Branches $^{\mathrm{b}}$ with smaller shares (mature branches) } \\
\hline Average & & 0.19 & 2.02 & 0.16 & 2.11 \\
\hline Total & & 1.93 & 20.20 & 1.56 & 21.13 \\
\hline 9 & 511 & 0.56 & 5.82 & 0.27 & 3.65 \\
\hline 10 & 562 & 0.34 & 3.58 & 0.25 & 3.39 \\
\hline 11 & 516 & 0.17 & 1.76 & 0.24 & 3.29 \\
\hline 12 & 512 & 0.24 & 2.48 & 0.22 & 3.01 \\
\hline 13 & 591 & 0.16 & 1.69 & 0.17 & 2.31 \\
\hline 14 & 233 & 0.16 & 1.64 & 0.12 & 1.63 \\
\hline 15 & 551 & 0.09 & 0.92 & 0.11 & 1.51 \\
\hline 16 & 266 & 0.12 & 1.22 & 0.09 & 1.18 \\
\hline 17 & 584 & 0.08 & 0.83 & 0.06 & 0.75 \\
\hline 18 & 572 & 0.02 & 0.24 & 0.03 & 0.40 \\
\hline
\end{tabular}

Source: Prepared by the author on the basis of ECLAC (1994).

a The branches are ranked according to their percentage share of world trade in 1993.

b Based on the Standard International Trade Classification (SITC).

three main branches accounted for $64 \%$ of the industry's share in the world petrochemical market. These branches are: i) petroleum products, ii) resins of polyethylene, polypropylene, PVC and ABS-SAN, and iii) plasticizers, oil additives and anti-detonants.
By 1993, however, this concentration tended to go down, largely because of the smaller share of the most mature basic goods -i.e., commodities, and especially petroleum products- in contrast with the increase in the share of final goods and petrochemical specialties (table 2). 


\section{VII}

\section{Results and types of technological maturity: the market and some variables}

In this section, technological maturity is analysed with the incorporation of the market share variable (y axis) and five other variables ( $\mathrm{x}$ axis), as shown earlier in figure 2.

\section{Market share and market dynamism: maturity of the market}

We will now analyse the dynamism of the international petrochemical market, which is different for innovative or dynamic products as against mature or non-dynamic goods: i.e., for those which grow more than the average for the total imports of the OECD between 1980 and 1993 on the international market as against those which grew less than the average.

This definition, which is based on the share of the PCI market in 1993, will represent our first identification of the maturity of the market, in which the dynamic products are the innovative ones and the non-dynamic products are the mature ones.

For the PCI as a whole, we note that the innovative branches are in the majority (10 out of 18), but the net result is negative (-23\%) because the mean negative growth of the mature branches $(-50 \%)$ was greater than the mean positive growth of the innovative branches $(+35 \%)$ (table 3 ).

Another noteworthy feature is that, as we shall see below, almost all the innovative branches coincide with those that have a greater content of technology. In contrast, in the mature branches the technological content is variable, so that they include branches with high and low contents of technology. ${ }^{15}$

\footnotetext{
15 This finding coincides with that obtained by Hochgraf (1983), cited in Gutiérrez (1988), for four of the five products on which he based his sample, namely, ethyl alcohol (group 512), benzene (group 511), synthetic fibres (group 266) and synthetic elastomers (group 233).
}

The mature branches were fewer in number ( 8 out of 18) and had a smaller share of the petrochemical market (44\%) in 1993, although they had had the largest share in $1980(68 \%)$.

The large share of petroleum products (group 334 ) is noteworthy (49\% in 1980 and $26 \%$ in 1993), but this was the branch that decreased most (58\%) (table 3).

The weight of the innovative branches is increasingly great. Between 1980 and 1993 their share increased by $35 \%$, because this category contains the most dynamic branches on the market, located further ahead in the petrochemical chain. Particularly rapid growth was registered by groups 514 -acrylonitrile, amides and anilines, with $80 \%$ - and 533 -pigments, paints and varnishes, with $60 \%$ (table 3 and figure 10).

This behaviour indicates that some of the branches of the PCI are, as we already noted, in a state of maturity or are being replaced by other products. It may also be noted that the dynamism of some branches is due to the fact that they provide inputs for products which are very dynamic on the international market, such as plasticizers in the electronics and motor industries or new materials for the manufacture of information processing, robotics and telecommunications equipment.

Some branches -especially those producing petrochemical specialties- have been so dynamic that they have even been classed as part of the new techno-economic paradigm, in which the spearhead sectors have a wide dissemination and presence in other sectors.

Among the branches with high market shares (over 4\%) there are six innovative branches (groups $583,514,582,598,533$ and 513) but only two mature branches (petroleum products and group 522) (table 3).

The results show that most of the 18 branches studied are innovative (10 out of 18 ) while the remainder are mature (figure 11). 
TABLE 3

Market dynamism in the world petrochemical industry, 1980-1993 ${ }^{\text {a }}$

\begin{tabular}{|c|c|c|c|c|c|c|}
\hline \multirow{3}{*}{\multicolumn{2}{|c|}{ Petrochemical branches ${ }^{b}$}} & \multicolumn{4}{|c|}{ Share of petrochemical branch } & \multirow{3}{*}{$\begin{array}{c}\text { Growth rate } \\
1980-1993 \\
(\%)\end{array}$} \\
\hline & & \multicolumn{2}{|c|}{1980} & \multicolumn{2}{|c|}{1993} & \\
\hline & & World market & PCI\% & World market & PCI\% & \\
\hline \multicolumn{7}{|c|}{ World petrochemical industry } \\
\hline Average & & 4.77 & 50.00 & 3.69 & 50.00 & -22.62 \\
\hline Total & & 9.54 & 100.0 & 7.38 & 100.0 & \\
\hline \multicolumn{7}{|c|}{ Dynamic (innovative) branches } \\
\hline Average & & 0.31 & 3.20 & 0.41 & 5.59 & 35.01 \\
\hline Total & & 3.05 & 32.01 & 4.12 & 55.85 & \\
\hline 1 & 514 & 0.35 & 3.64 & 0.62 & 8.45 & 79.72 \\
\hline 2 & 533 & 0.20 & 2.09 & 0.32 & 4.32 & 59.68 \\
\hline 3 & 516 & 0.17 & 1.76 & 0.24 & 3.29 & 44.73 \\
\hline 4 & 598 & 0.48 & 5.07 & 0.66 & 8.94 & 36.33 \\
\hline 5 & 572 & 0.02 & 0.24 & 0.03 & 0.40 & 27.73 \\
\hline 6 & 513 & 0.24 & 2.53 & 0.31 & 4.16 & 27.24 \\
\hline 7 & 551 & 0.09 & 0.92 & 0.11 & 1.51 & 27.06 \\
\hline 8 & 583 & 0.94 & 9.82 & 1.18 & 15.98 & 25.89 \\
\hline 9 & 582 & 0.40 & 4.24 & 0.48 & 6.49 & 18.59 \\
\hline 10 & 591 & 0.16 & 1.69 & 0.17 & 2.31 & 5.43 \\
\hline \multicolumn{7}{|c|}{ Non-dynamic (mature) branches } \\
\hline Average & & 0.81 & 8.50 & 0.41 & 5.52 & -49.76 \\
\hline Total & & 6.49 & 67.99 & 3.21 & 44.15 & \\
\hline 11 & 512 & 0.24 & 2.48 & 0.22 & 3.01 & -5.96 \\
\hline 12 & 522 & 0.36 & 3.73 & 0.30 & 4.12 & -14.40 \\
\hline 13 & 233 & 0.16 & 1.64 & 0.12 & 1.63 & -23.14 \\
\hline 14 & 266 & 0.12 & 1.22 & 0.09 & 1.18 & -25.27 \\
\hline 15 & 562 & 0.34 & 3.58 & 0.25 & 3.39 & -26.78 \\
\hline 16 & 584 & 0.08 & 0.83 & 0.06 & 0.75 & -30.01 \\
\hline 17 & 511 & 0.56 & 5.82 & 0.27 & 3.65 & -51.51 \\
\hline 18 & 334 & 4.64 & 48.69 & 1.95 & 26.41 & -58.02 \\
\hline
\end{tabular}

Source: Prepared by the author.

a The branches are ranked according to their percentage growth rates.

${ }^{\mathrm{b}}$ Based on the Standard International Trade Classification (SITC).

FIGURE 10

Growth rates of market shares of some branches of the world petrochemical industry, 1980-1993

(Percentages)

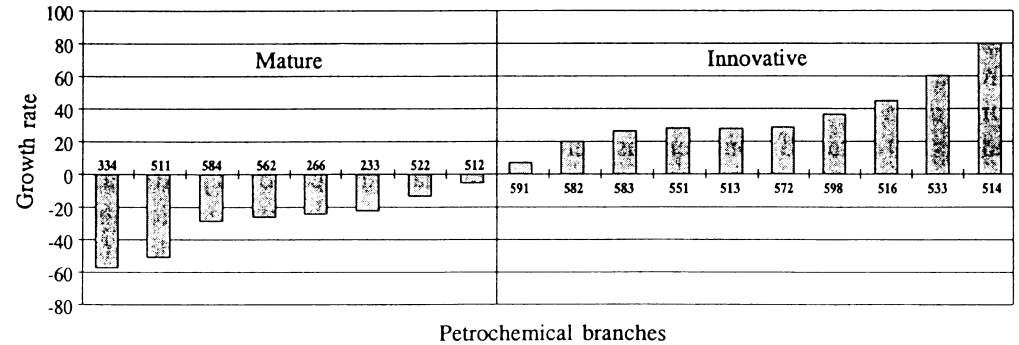

Source: Prepared by the author on the basis of table 3 . 
FIGURE 11

Final results by type of technological maturity of $\mathrm{PCI}$ branches ${ }^{\mathrm{a}}$

\begin{tabular}{|c|c|c|c|c|c|c|c|}
\hline $\begin{array}{c}\text { PCI } \\
\text { branches }\end{array}$ & $\begin{array}{c}\text { Market } \\
\text { share } \\
\text { (MS) }\end{array}$ & $\begin{array}{c}\text { Market } \\
\text { dynamism } \\
\text { (MD) }\end{array}$ & $\begin{array}{c}\text { MS } \\
\text { MD }\end{array}$ & $\begin{array}{c}\text { Produc- } \\
\text { tion }\end{array}$ & Patents & $\begin{array}{c}\text { Produc- } \\
\text { tion } \\
\text { chain }\end{array}$ & $\begin{array}{c}\text { Evolu- } \\
\text { tionary }\end{array}$ \\
\hline 233 & M & M & M & M & M & I & M \\
\hline 266 & M & M & M & M & M & I & M \\
\hline 334 & I & M & M & M & I & M & M \\
\hline 511 & M & M & M & M & I & M & M \\
\hline 512 & M & M & M & I & M & M & M \\
\hline 513 & I & I & I & I & I & M & M \\
\hline 514 & I & I & I & I & I & M & M \\
\hline 516 & M & I & I & M & M & M & M \\
\hline 522 & I & M & M & I & I & M & M \\
\hline 533 & I & I & I & M & I & I & M \\
\hline 551 & M & I & I & I & I & I & I \\
\hline 562 & M & M & I & I & M & M & I \\
\hline 572 & M & I & I & M & I & I & M \\
\hline 582 & I & I & I & I & I & I & I \\
\hline 583 & I & I & I & I & I & I & I \\
\hline 584 & M & M & M & I & M & M & M \\
\hline 591 & M & I & I & I & I & I & I \\
\hline 598 & I & I & I & I & M & I & M \\
\hline
\end{tabular}

Source: Prepared by the author.

${ }^{a} \mathrm{M}=$ mature; $\mathrm{I}=$ innovative.

b Based on the Standard International Trade Classification (SITC).

\section{Market share and dynamism of production: maturity of production}

Dynamism of production is based on the growth of the volume of world production (in metric tons) shown in the statistics of United Nations (1993 and 1994), harmonized with the SITC.

Maturity of production is defined by the growth of petrochemical products compared with the average for industry as a whole.

Innovative branches are those which had a positive mean growth rate between 1980 and 1992 compared with the average for all petrochemical branches; mature branches are those which had a negative growth rate compared with that average.

The behaviour of the PCI has varied from one branch to another. Generally speaking, the behaviour of world production (figure 12) displays well-defined analytical categories in terms of the petrochemical cycle.
FIGURE 12

Growth rates of volume of world petrochemical production, 1977-1992

(Metric tons and percentages)
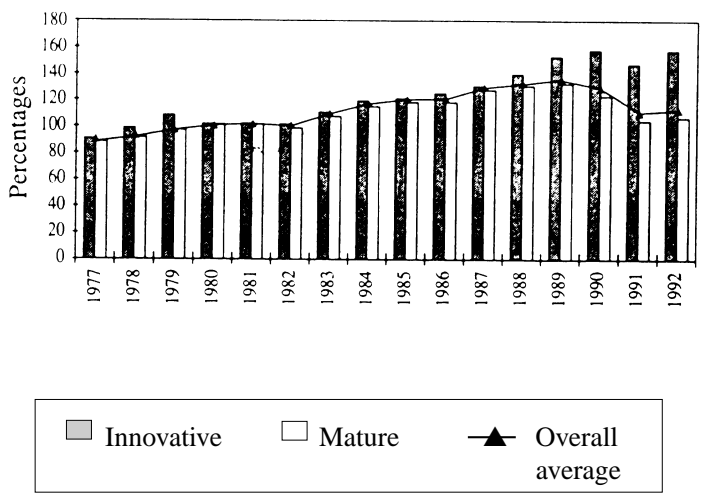

Source: Prepared by the author on the basis of United Nations (1993 and 1994). 
TABLE 4

Rate of patent applications in the world petrochemical industry, 1983-1994

(Percentages of number of patents registered in the United States)

\begin{tabular}{|c|c|c|c|c|}
\hline \multicolumn{2}{|l|}{ Branches $^{\text {a }}$} & Products of branch & Growth rate $(\%)$ & Share $(\%)$ \\
\hline \multicolumn{5}{|l|}{ World PCI } \\
\hline Total & & & 0.03 & 100.0 \\
\hline Average & & & & 5.56 \\
\hline \multicolumn{5}{|c|}{$\begin{array}{l}\text { Branches with a high rate of patent } \\
\text { applications (innovative) }\end{array}$} \\
\hline Total & & & 0.80 & 46.04 \\
\hline Average & & & 0.08 & 4.60 \\
\hline 1 & 582 & Polyamides, PET & 0.12 & 4.50 \\
\hline 2 & 551 & Perfumes and flavourings & 0.10 & 0.29 \\
\hline 3 & 533 & Varnishes, pigments & 0.09 & 4.01 \\
\hline 4 & 513 & Carboxylic acids & 0.09 & 6.55 \\
\hline 5 & 583 & Polyethylene, PVC & 0.08 & 6.14 \\
\hline 6 & 514 & Anilines, amides & 0.08 & 3.94 \\
\hline 7 & 334 & Olefins & 0.07 & 5.96 \\
\hline 8 & 511 & Ethylene, toluene, benzene & 0.07 & 13.45 \\
\hline 9 & 572 & Explosives and pyrotechnic products & 0.05 & 0.68 \\
\hline 10 & 591 & Insecticides, fungicides & 0.04 & 0.52 \\
\hline \multicolumn{5}{|c|}{$\begin{array}{l}\text { Branches with a low rate of patent } \\
\text { applications (mature) }\end{array}$} \\
\hline Total & & & -0.02 & 53.96 \\
\hline Average & & & - & 6.75 \\
\hline 11 & 512 & Phenols, alcohols & 0.02 & 16.32 \\
\hline 12 & 584 & Esters, ethers & 0.02 & 14.70 \\
\hline 13 & 266 & Synthetic fibres, nylon & 0.01 & 2.70 \\
\hline 14 & 233 & SBR, latex & 0.01 & 3.27 \\
\hline 15 & 598 & Oil additives & 0.01 & 2.74 \\
\hline 16 & 522 & Carbon black, nitric acid & - & 2.78 \\
\hline 17 & 516 & Formaldehyde, acetaldehyde & -0.04 & 4.39 \\
\hline 18 & 562 & Urea, phosphates & -0.05 & 7.07 \\
\hline
\end{tabular}

Source: Prepared by the author on the basis of data from the U.S. Patent Office.

${ }^{\text {a }}$ Based on the Standard International Trade Classification (SITC).

Noteworthy among the innovative branches are those manufacturing final products such as polypropylene, phenolic resins, acetates and polystyrene (groups 582, 583, 514, 598, 513, 522, 591, 584, 512 and 562).

Among the mature branches, there are many which produce basic goods such as benzene, butadiene, carbon black, ammonia, and some intermediate goods such as ethylene glycol, ethylene oxide and phenol (groups 334, 533, 266, 572, 511, 233 and 516) (figure 11).

In most of the branches the results with regard to maturity of production are similar to those for market maturity, except in the case of seven branches (groups 512, 516, 522, 533, 562, 572 and 584).

\section{Market share and intensity of applications for patents: maturity in terms of applications for patents}

Patents have been used as one of the technological indicators, since they reflect the results of inventiveness and changes in products and/or processes. ${ }^{16}$

\footnotetext{
${ }^{16}$ Among the indicators relating to intellectual property, one of the most accessible and useful in the case of the PCI is that regarding patents. Another potentially useful but not readily accessible indicator is that relating to "industrial secrets". With regard to the advantages and disadvantages of this indicator for measuring the process of innovation, see Griliches (1990), Dosi, Freeman, Nelson and others (1988) and Dosi, Pavitt and Soete (1990).
} 
Patents are one of the means whereby entrepreneurs protect their inventions and innovations. This means of protection allows them to maximize their monopolistic gains from innovation by making it more difficult for potential competitors to copy or imitate them.

Patents capture and measure the first stages of a process which, through development, testing and engineering, leads from the invention itself to the complete innovation. Patents can extend over the whole product cycle, from those which protect the basic invention, through those relating to the product and process engineering, and finally a large number of patents to protect improvements and block action by competitors (Dosi, Pavitt and Soete, 1990).

In this study, measuring the intensity of patent applications is effected by identifying the branches of the PCI in which most patents are taken out (table 4). Branches defined as innovative are those where there was positive growth in the rate of applications for patents between 1983 and 1994, while mature branches are those where growth in this rate was negative. This reflects a certain ageing of the products concerned, with prevalence of those where fewest patents are taken out: branches using technologies which have been covered for 20 years by the patents obtained. The period selected was from 1983 to 1994 in order to maintain compatibility with the periods used for studying the other variables ${ }^{17}$ (table 4 ).

The results obtained between 1983 and 1994 show that the innovative branches as a whole registered a larger number of patents (four or five times more than the mature branches between 1969 and 1996). However, it has been noted that it is not necessarily the most dynamic branches in terms of patent applications which account for the largest share of patents (measured in relation to the number of patents registered in the United States), although in some cases there is indeed a strong correlation between the rate of applications for patents and market shares.

Thus, for example, some innovative branches (groups 551, 572 and 591) display considerable dynamism in terms of patent applications (rates of 0.10,

${ }^{17}$ If we had selected a longer series this would have enabled us to determine the results in terms of maturity more precisely, since it would include innovations made before the period in question, many of which may have been the basis for subsequent developments, and it would also have made it possible to determine the radical or incremental nature of the innovations.
FIGURE 13

\section{Rate of patent applications of}

some PCI branches, 1969-1996

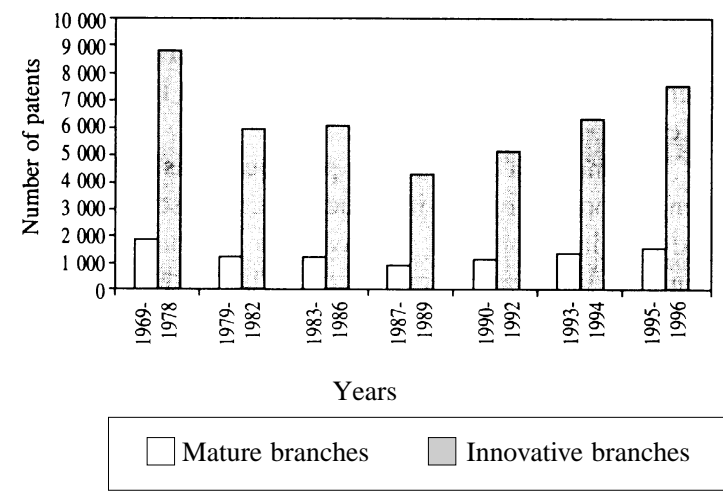

Source: Prepared by the author on the basis of data from the U.S. Patent Office.

0.05 and $0.04 \%$ respectively) yet have low shares of the number of patents registered $(0.29,0.68$ and $0.52 \%$ respectively). Conversely, some mature branches (groups 512, 584 and 562) account for a greater share of patents but display low levels of dynamism in this respect $(0.02,0.02$ and $-0.05 \%$ respectively).

This result confirms that many of the mature branches correspond to commodity producers and that although some of these branches have made changes or improvements which are reflected in patents, these are much fewer than in the innovative branches. This tendency also shows how much importance the companies have attached to intellectual protection through patents (figure 13).

The results obtained by combining patent dynamism with market share show that almost half of the PCI ( 8 out of 18 branches) is in mature branches (groups 598, 522, 512, 584, 266, 233, 516 and 562), while a little more than half (10 out of 18) corresponds to innovative branches (groups 582, 533, 513, 583, 514, 334, 551, 572, 511 and 591) (figure 11).

\section{Market share and the production chain: maturity in the production chain}

The analysis of technological maturity is further completed by determining the location of each branch in the production chain (figure 6) and in the life cycle of its products (figure 5), in order to identify the degree of maturity of the two typical lines of 
business of the PCI -commodities and specialtiesreferred to at the beginning of this article.

The petrochemical chain (figure 4) is divided in this case into two major stages. The first comprises steps 1 and 2, which involve the production of commodities and intermediate products and are marked by maturity. The second stage comprises steps 3 and 4 , which correspond to final goods and petrochemical specialties such as resins, fibres and rubber inputs and are innovative products.

The further along the petrochemical chain, the greater will be the technological content. Consequently, the mature branches are those which produce commodities and are located in the first stage of the chain, while the innovative branches are those that produce petrochemical specialties and are located in the second stage.

The results show that, as we saw when looking at the previous types of maturity, most of the branches (10 out of 18) are innovative (groups 533, 582, 583, 598, 233, 266, 516, 551, 572 and 591), while the remaining eight are mature (groups 334, $513,514,522,511,512,562$ and 584). These results show that commodities or specialties may be in the innovative or mature stages, depending on the criteria used (figure 11).

\section{Market share and technological taxonomy: maturity of evolution}

The technological content as defined by the maturity of evolution shows the variety of forms of technological behaviour of the enterprises studied and is based on the taxonomy prepared by Pavitt (1984).

This taxonomy identifies the different levels of innovation of economic sectors and proposes four technological categories corresponding to different forms and intensities of innovation, namely: i) supplier-dominated forms; ii) "scaleintensive" forms; iii) those having a specialized supplier, and iv) science-based forms. The differences in each category vary according to the origin of the technology, the supplier-user relationship and the possibility of appropriating technological rents.

The composition of each branch with regard to these categories determines the innovative or maturity potential of each industry, taken as a whole.

In this taxonomy, the mature branches (groups 233, 266, 334, 511, 512, 513, 514, 516, 522, 533,
572, 562, 584 and 598) are those which correspond to the categories defined by Pavitt as being supplier-dominated or "scale-intensive" (figure 11).

The traditional branches, in many cases producing commodities, are to be found in this category. They are also branches which use widely available technology, make few investments in scientific and technological research, and have only limited infrastructure. There is a high possibility of imitation, so the level of appropriation is low. The means of appropriation used are brand names, product differentiation, industrial secrets and patents. These characteristics mean that there are few innovations, usually of an incremental nature, because there are few efforts or results in the field of innovation. Technological changes involve above all the machinery and equipment, or else large-scale production associated with the equipment.

The rest of the branches (groups 551, 582, 583 and 591) are the innovative ones and belong to the categories of specialized suppliers and science-based branches (figure 11).

These categories are marked on the one hand by being producers of specialized machinery, equipment and instruments and, on the other, by assimilating and applying scientific knowledge developed in the technology centres of the companies themselves or in institutions such as universities or research centres.

Innovation is mainly at the product level, and the type of technological change is primarily radical or major. The rents from the technology are generally high and are based on a very close interrelation with users. In research activities, the predominant areas are those of know-how, design, quality, patents, and industrial secrets. In both categories, the innovations range from incremental and widely disseminated developments to radical innovations, thus pointing to greater innovative activity than in the mature branches.

The results obtained in terms of maturity by combining market share with the technological taxonomy show that the performance of the PCI as a whole bears out the initial argument of this article, which emphasizes that maturity varies from one branch to another in the PCI.

The majority of the petrochemical branches (14 out of 18) have little innovative activity, as highlighted in Pavitt's taxonomy, so that the PCI as a whole is marked by relative maturity (figure 11), 
with most branches (14 out of 18) being mature and only the remaining four being innovative.

\section{The petrochemical industry as a mature industry with some innovative branches: a summary}

As a whole, the PCI is a mature industry, as reflected in its market, production and technological results. At the level of its individual branches, however, the situation in terms of maturity is not always the same, as it can vary depending on the indicator used (figure 11).

In 12 of the 18 branches studied, the variables used give complementary results in terms of maturity or technological innovation. In the remaining six branches, however, there are contradictions as regards whether they are mature or innovative. If we take the differentiation between commodities and specialties, we likewise see that there are both coincidences and contradictions with regard to the concept of maturity (figure 11).

If we take all the variables, 8 out of the 18 petrochemical branches (groups 233, 266, 334, 511, 512, 522,562 and 584) prove to be preponderantly mature in the sense that the maturity indicator coincides in at least five variables.

The preponderantly innovative branches are in the minority ( 4 out of 18 : groups 551, 582, 583 and 591). They have characteristics and rates typical of innovation and correspond to branches in which the innovation indicator coincided in five out of six of the variables used.

The remaining six branches out of the 18 (groups 513, 514, 516, 533, 572 and 598) may be defined as either mature or innovative, depending on the variable used.

\section{VIII}

\section{Conclusions}

The analysis of technological maturity must be seen as a complex and evolutionary process in which the technological dimension, in combination with the market, production and the production chain, may maintain or modify the degree of maturity.

The measurement of technological maturity varies according to the indicators used in it, and this
These results show that the criteria usually applied to distinguish between mature and innovative branches do not necessarily coincide with those used by technical experts, academics or the specialized press. This also applies to the distinction between the commodity and specialty lines of business in the industry.

Finally, the direction of causality has been determined between each of these variables, in order to provide even stronger grounds for the conclusions reached. The basis for the analysis was the application of the coefficient of correlation by ranks (Spearman's index) to the quantitative variables, market share (MS), market dynamism (MD), production dynamism (PD) and rate of patent applications (PA).

Synthesis of the results in terms of market share and measurement of technological maturity shows a weak positive correlation between MS and MD $(=0.19)$, MS and PD $(=0.21)$ and MS and PA $(=0.18)$. These data show that although the coefficients of correlation are positive, they are different in the three cases and the case which best explains the causality is that which combines market share with production dynamism.

The index of correlation is as follows: ${ }^{18}$

$$
r_{K}=1-\frac{6 \sum d^{2}}{n\left(n^{2}-1\right)}
$$

where $d$ is the difference between pairs of corresponding ranks and $n$ is the number of pairs.

However, it is also necessary to take into account the characteristics relating to purely technological aspects, as noted earlier for the variables relating to patents, the production chain and intensity of innovation.

may lead to differing results with regard to the definition of branches as mature or innovative. The criteria for defining maturity are neither clear nor

\footnotetext{
${ }^{18}$ The distribution in the sample is symmetrical around 0 and ranges from -1 to +1 .
} 
precise, and this highlights the importance of making them more uniform in order to be able to classify products as mature or innovative.

When only market variables or those typical of comparative advantages are taken into account for measuring maturity, differences and contradictions arise in the resulting degrees of maturity. The analysis should therefore include not only market share and production dynamism but also other variables (especially those of a technological nature) which help to explain the dynamics of the cycle.

Performance in terms of innovation in the PCI is specific to each of the branches making up the industry: that is to say, it is differentiated. The combination of the various criteria for analysing technological maturity has given different results for different branches, thus giving different types of maturity. Two types of branches have been identified in the petrochemical industry: innovative branches, which are those where technological activity is greatest but do not always obtain outstanding results in the market and are generally engaged in the production of petrochemical specialties, and mature branches, which register a lower level of technological activity, with variable market results, and are generally engaged in the production of commodities.

Combination of the different variables and indicators used (market share, share in production, rate of patent application activity, place in the production chain, and technological taxonomy) gave rise to types and states of maturity which coincided in many cases with the results for each variable analysed, with weak positive levels of correlation between the variables.

In the set of variables analysed it was found that the innovative branches, which are generally specialized, tend to have a greater presence on international markets. This result was observed in the branches located in the more advanced steps of the petrochemical chain, corresponding to goods with more technological content and greater added value. There can also be innovative branches which have poor market results, however. In this case, their market position can improve if there is a substantial demand push, or get worse if this does not exist or the other branches improve their technological situation. In other words, petrochemical specialties do not always have excellent market results, even though they generally have a favourable position in the international market.

The mature branches, for their part, which are generally engaged in the production of commodities, have intermediate market results: they may have an important presence in the market, generally in specific niches, or they can tend to be replaced by new branches. Generally speaking, they are towards the end of the production life cycle and at the beginning of the production chain, and their position in the international market is usually unfavourable.

The analysis of technological maturity can be useful for showing the form of insertion in the international economy of the leading countries and those that follow them. The leaders set the pace of international technological competitiveness, which is related in practice with the technological frontier and innovative products and processes. In contrast, the international insertion of the followers is usually in less innovative, mature, product lines and processes, generally associated with commodities.

The application of this methodology at the country or enterprise level can show how the different countries operate and their position in the economy. The division of the world market into innovative and mature branches is useful for understanding and justifying sectoral lines of competition, in terms of the market and technological results, which help to identify or strengthen the international competitiveness of a country or enterprise. It can also aid in the analysis of the respective macroeconomic configurations and hence serve as a guide in the application of forward-looking structural reforms, identifying the strengths, weaknesses and opportunities of the different types of international insertion, in mature or innovative branches.

This analysis should be complemented with an examination of the scenario represented by a system or policy of innovation at the regional and national level aimed at reducing the effects of international recessions or deterioration in the terms of trade on the mature branches, which are more seriously affected by these phenomena than the innovative branches.

In the future, maturity studies of this nature could help in the analysis of international trade specialization and the results of technological change in terms of competitiveness. The results regarding positioning would help to go more deeply into the causes and possibilities of improving or modifying the position occupied by a country or enterprise and its type of international insertion.

The foregoing suggests various lines of future research. One of these would be to apply the study of technological maturity to other economic branches. 
Another would be to identify the results obtained by a country's industry at the international level and see whether they coincide with the performance of enterprises within that country.

It is important to make studies in greater depth at the enterprise level and find aspects which are not visible from the indicators and statistics at the country, industry or product level. In order to do this, the strategic performance of enterprises and their capacity for learning and developing technological skills should be analysed and then included in the examination of market and technological variables, in order to identify possible relations and common characteristics between the enterprises and institutions in question.

(Original: Spanish)

\section{Bibliography}

Achilladelis, B. A. Schwarzkopf and M. Cines (1990): The dynamics of technological innovation: The case of chemical industry, Research Policy, vol. 19, No. 19, Amsterdam, Netherlands, North Holland.

Amable, B. (1993): National effects of learning, international specialization and growth paths, in C. Freeman and D. Foray (eds.), Technology and the Wealth of Nations: The Dynamics of Constructed Advantage, New York, St. Martin's Press.

Arjona, L. (1995): La tecnología en la teoría del comercio: la perspectiva evolutiva, El trimestre económico, vol. LXII, No. 248, Mexico City, Fondo de Cultura Económica (FCE).

Arjona, L. and K. Unger (1996): Competitividad internacional y desarrollo tecnológico: la industria manufacturera mexicana frente a la apertura comercial, Economía mexicana, vol. V, No. 2, Mexico City, Center for Economic Research and Training (CIDE).

Bower, J. (1985): Restructuring petrochemicals: A comparative study of business and government strategy to deal with a declining sector of the economy, in B. Scott and G. Lodge (eds.), U.S. Competitiveness in the World Economy. A Harvard Business School Research Colloquium, Boston, Massachusetts, Harvard Business School Press.

Chapman, K. (1991): The International Petrochemical Industry: Evolution and Location, London, Basil Blackwell Ltd.

Chudnovsky, D., A. López and F. Porta (1994): The petrochemical and machine tool industries: Business strategies, CEPAL Review, No. 52, LC/G.1824-P, Santiago, Chile, Economic Commission for Latin America and the Caribbean (ECLAC).

Chudnovsky, D. and F. Porta (1997): Auge y ocaso del capitalismo asistido. La industria petroquímica latinoamericana, Santiago, Chile, ECLAC/International Development Research Centre (IDRC)/Alianza Editorial.

Dosi, G. (1982): Technological paradigms and technological trajectories. A suggested interpretation of determinants and directions of technical change, $R e$ - search Policy, vol. 11, Amsterdam, Netherlands, North Holland.

Dosi, G., C. Freeman, R. Nelson and others (1988): Technical Change and Economic Theory, London, Pinter Publishers.

Dosi, G., K. Pavitt and L. Soete (1990): The Economics of Technical Change and International Trade, London, Harvester Wheatsheaf.

ECLAC (Economic Commission for Latin America and the Caribbean) (1993): Progreso técnico y competitividad internacional, LC/R.1104, Santiago, Chile, Joint ECLAC/UNIDO Industrial and Technological Development Unit.

(1994): Competitive Advantage of Nations, Santiago, Chile.

Fajnzylber, F. (1991): International insertion and institutional renewal, CEPAL Review, No. 44, LC/G.1667-P, Santiago, Chile, ECLAC.

Freeman, C. (1974): The Economics of Industrial Innovation, Harmondsworth, Middlesex, U.K., Penguin Books Ltd.

Freeman, C., J. Clark and L. Soete (1982): Unemployment and Technical Innovation. A Study of Long Waves and Economic Development, London, Frances Pinter Ltd.

Griliches, Z. (1990): Patent statistics as economic indicators: A survey, Journal of Economic Literature, vol. 28, No. 4, Nashville, Tennessee, American Economic Association.

Gutiérrez, R. (1988): Maduración tecnológica y perspectivas de la indústria petroquímica mundial, Economía de América Latina, No. 17, Mexico City, CIDE.

Jasso, J. (1997): Competitividad internacional empresarial: intensidad patentadora y de mercado, Espacios. Revista Venezolana de Gestión Tecnológica, vol. 18, No. 1, Caracas.

Nelson, R. and S. Winter (1982): An Evolutionary Theory of Economic Change, Cambridge, Massachusetts, Cambridge University Press. 
Pavitt, K. (1984): Sectoral patterns of technological change, Research Policy, No. 13, Amsterdam, Netherlands, North Holland.

Rothwell, R. (1994): Industrial innovation: success, strategy, trends, in D. Mark and R. Rothwell (eds.), Handbook of Industrial Innovation, London, Edward Elgar.

Unger, K., L. Saldaña, J. Jasso and G. Durand (1994): Ajuste estructural y estrategias empresariales en
México. Las industrias petroquímica y de máquinas-herramientas, Mexico City, CIDE.

United Nations (1993): Industrial Statistics Yearbook 1991, New York, United Nations Statistical Office.

(1994): Industrial Commodity Statistics Yearbook 1992, New York, United Nations Statistical Office. Walsh, V. (1984): Invention and innovation in the chemical industry: Demand-pull or discovery-push?, Research Policy, vol. 3, No. 4, Amsterdam, Netherlands, North Holland. 